\title{
Bizmut-BAL Şelatı Sentezinin Optimizasyonu ve Escherichia coli, Streptococcus pyogenes ve Aktif Çamur Üzerindeki İnhibisyon Etkisi
}

\author{
Synthesis Optimization and Inhibition Effects of Bismuth- \\ BAL Chelate on Escherichia coli, Streptococcus pyogenes, and \\ Activated Sludge
}

\author{
Börte Köse-Mutlu',2 (D) Türker Türken ${ }^{1,3} \mathbb{( D}$, Selin Okatan ${ }^{1}$ (D), Gamze Durmaz ${ }^{1}$ (D), \\ Melike Ürper-Bayram ${ }^{1,3}$ (D) , Serkan Güçlü 1,3 (D), Süleyman Övez ${ }^{3}$ (D) , İsmail Koyuncu \\ $1,3, *$ (1) \\ 1, Prof. Dr. Dincer Topacık Ulusal Membran Teknolojileri Uygulama ve Araştırma Merkezi, İstanbul Teknik Üniversitesi, \\ İstanbul, TÜRKIYE \\ 2, Yeditepe Üniversitesi, Mühendislik Fakültesi, İnşaat Mühendisliği Bölümü, İstanbul, TÜRKiYE \\ ${ }^{3}$ İstanbul Teknik Üniversitesi, İnşaat Fakültesi, Çevre Mühendisliği Bölümü, İstanbul, TÜRKIYY \\ Sorumlu Yazar / Corresponding Author*: koyuncu@itu.edu.tr
}

Öz

Teknoloji ve mühendisliğin gelişmesi ile beraber yüksek kalitede pek çok ürünün üretimi ve geniş kullanım alanlarında yeralması mümkün olmaktadır. Bu yüksek kalitedeki mikro- ve nanoteknolojik malzemeler bakteri kolonileri ve biyofilm tabakaları tarafından kolayca sarılmaktadırlar. Araştırmacılar, bu probleme çözüm bulabilmek adına pek çok farklı antibakteriyel kimyasal sentezlemişlerdir. Uzun bir süredir, hücredışı polimerik maddeler (EPS) ve çözünmüş mikrobiyal ürünler (SMP) sebebiyle porlarda ve yüzeylerde gerçekleşen biyofilm oluşumu mühendislik uygulamalarının bir problemi olarak gösterilmektedir. Mikroorganizmalar sentezlenen bizmut-BAL şelatı (Bis-BAL) na maruz kaldığında toplam polisakkaritleri ve proteinleri daha az salgılarlar. $\mathrm{Bu}$ çalş̧mada Escherichia coli ve Streptococcus pyogenes tarafindan salgılanacak EPS ve SMP'nin engellenmesi öngörülmüștür. Bizmut metali ve lipofilik tiyolün çeşitli konsantrasyonlarının kombinasyonlar halinde denenmesi ile sentezlenen kimyasallar arasından en yüksek inhibisyon etkisini gönderenin belirlenmesi amaçlanmıştır. Bis-BAL'ın uygulanmasıda izlenebilecek stratejiler ve stabilitesi de çalışılmıștır. İlgili șelat membran biyoreaktörlerde kullanılacak olan membranların bünyesine ilave edilebilir ve böylelikle doğal su kaynaklarının kalitesinin korunarak su ihtiyacının karșılanmasında tercih edilen membran teknolojisinde biyotıkanmanın önüne geçilebilir.

Anahtar Kelimeler: Antibakteriyel Ürün, Bizmut, Minimum İnhibisyon Konsantrasyonu, Karışılk Kültür; Saf Bakteri Kültürü. 


\begin{abstract}
With the development of technology and engineering, different highly qualified products can be manufactured and used with a wide range. This highly qualified micro- and nano-technological materials can be easily covered with bacteria colonies and biofilms. Researchers have tried to synthesize different anti-bacterial chemicals to solve this problem. The formation of biofilm on the surface and in the pores, which is caused by the extracellular polymeric substances (EPS) and soluble microbial products (SMP), has long been identified as a problem for engineering applications. The total polysaccharides and proteins secreted by microorganisms can be decreased when exposed to the synthesized bismuth-BAL chelate (BisBAL). Our proposal is to inhibit the EPS and SMP from Escherichia coli and Streptococcus pyogenes. The anti-bacterial properties of synthesized chemicals that have several combinations of bismuth metal with lipophilic thiol compound were examined to get the optimum inhibitor. The application strategies and stability of BisBAL were also studied. The chelate can be used as a compound of membranes used in membrane bioreactors, which will be an obligation of advanced wastewater treatment with the aims of the protection of natural water sources' quality and supply the water demand, to prevent the biofouling.
\end{abstract}

Keywords:Anti-bacterial Product, Bismuth, Minimum Inhibition Concentration, Mixed Culture, Pure Bacteria Culture.

\section{Giriș}

Membran teknolojisi, su ve atıksu arıtımında kullanılan aritma teknolojileri arasında en yüksek arıtma verimine sahip ve elverişli olandır. Membranlar por çaplarına göre partiküllere karşı seçici geçirgen davranış sergileyen ara yüzeylerdir [1]. Membran biyoreaktörler (MBR) ise membran teknolojisi ile biyolojik aritma prosesini biraraya getirir ve dünya pazarındaki yerini son 10 yılda işletme maliyetlerinde ortaya çıkan azalma sayesinde hızla arttırmıștır [2]. Üretilen membranlara anti-biyotıkanma özelliğinin verilemebilmesi amacıyla üretim sırasında çeșitli malzemeler ve/veya kimyasallar ilave edilebilir. Biyotıkanma problemine çözüm bulunabilmesi, daha az hacim ihtiyacı ve daha kısa hidrolik bekletme süreleri gibi avantajlara sahip MBR teknolojisinin pazardaki yerini büyütmesinin önündeki en büyük engelin kalkması anlamına geleceği için oldukça önemlidir.

Malzemelerde iki tip biyotıkanma gözlenir: tersinir ve geri dönüşümsüz biyotıkanma. Mühendislik ürünleri kullanım ömürleri içerisinde fiziksel ve kimyasal temizlemeye tabi tutulurlar fakat bazen temizleme prosedürünün sonunda kirliliğin kalabildiği gözlenir. $\mathrm{Bu}$ kirlenme, geri dönüşümsüz kirlenme olarak sinıflandırılır ve biyokek de bu sinıftaki oluşumlardan biridir. Genelikle, biyofilmler kolonize yüzeyler, içiçe geçmiş hücredışı polimerler, mikrobiyal hücreler tarafından olușturulmuș iyon kanallarından olușur ve kalınlıkları mikron boyutlarındadır $[3,4]$.
Biyotıkanmanın çözümü için biyofilm oluşumunun en başından engellenmesi gerekmektedir. Tarihsel uygulamalara bakıldığında, gümüş, altın, çinko, bakır, titanyum, selenyum ve bizmut gibi metallerin antibakteriyel ve anti-biyotıkanma özellikleri sebebi ile kullanıldığı görülmektedir [5-19]. Bu metaller, eklendikleri ürüne antibakteriyel özelliği kazandırırlar ve bu antibakteriyel özellik ise üç ana mekanizmaya dayanmaktadır: 1) yeni bakteri hücresinin hücre duvarı sentezinin bloklanması, 2) bakterinin hücre duvarının seçiciliğinin zedelenmesi ve 3) protein sentezinin durdurulması [20]. Antibakteriyel maddeler, bakterilerin ölümüne sebep olabilir ya da mikrobiyal ürünlerinin sentezini durdurabilir. Antibakteriyel etkinin hangi seviyede gözleneceği bakteri türüne göre değişkenlik gösterir. Bu durum genellikle türün gram-negatif veya gram-pozitif olması ile alakalıdır. İnhibisyon seviyesi çoğunlukla minimum inhibisyon konsantrasyonu (MİK) ile ifade edilir ve gram-pozitif bakteriler peptidoglikan molekülleri ile negatif yükleri sebebiyle gram-negatif bakterilerden daha hassastırlar [21]. Daha önce, gümüş metalinin gram-pozitif bir tür olan Staphylococcus aureus üzerindeki antibakteriyel etkisi çeșitli çalışmalarda ortaya konulmuştur [7, 8]. Altın metalinin de hem gram-pozitif hem de gramnegatif türler için antibakteriyel olarak başarı ile kullanılmıştır $[9,10]$. Çinko oksit, bakır, titanyum ve selenyum üzerine de çalışmalar mevcut olup her iki grupta da (gram-pozitif ve gram-negatif)etkili oldukları gözlenmiştir [11- 
15]. Bizmut metali ve çeșitli bizmut bileșenlerinin de antibakteriyel ajan olarak kullanıldığı bilinmektedir [16, 17]. En bilinen ant-biyotıkanma özellikli bizmut bileșenleri, bizmut tiyolleridir. $\mathrm{Bu}$ tiyol bileșikleri, EPS üretimini azalatır ve biyofilm oluşumunu kontrol altına alır. Bizmut tiyolleri bakterileri \%70-90 aralığında bir verim ile etkiler ve diğer antibakteriyel kimyasallardan daha güvenlidirler $[18,19]$. Bizmut ve lipofilik tiyoller, $\mu \mathrm{mol} / \mathrm{L}$ seviyelerindeki düșük konsantrasyonlarda bile antibakteriyel özellik gösterirler [20] ve hem gram-pozitif hem de gram-negatif türler üzerinde etkilidirler [21]. BisBAL ise laboratuvarda sentezlenen ve diğer bizmut bileșiklerinden 1000 kat daha fazla antibakteriyel özellik sergileyebilen bir bizmut tiyolüdür [22]. BisBAL'in EPS ve SMP üretimini ve salgılanmasını ve dolayısı ile biyofilm oluşumunu azalttığı bilinmektedir [21].

$\mathrm{Bu}$ çalışmada, BisBAL sentezi çeşitli koşullar denenerek optimize edilmiş ve şelatın inhibisyon etkisi gram-negatif ve gram-pozitif bakteriler üzerinde denenmiștir. Gram-negatif bakterileri temsil etmesi açısından Escherichia coli tercih edilirken gram-pozitif bakteri olarak Streptococcus pyogenes ile çalıșılmıștır. Ayrıca, karıșı kültür üzerindeki etkilerin de gözlenebilmesi amacıyla aktif çamur üzerinde de denemeler gerçekleştirilmiştir. BisBAL'ın membran üretiminde katkl maddesi olarak kullanılabilmesi için potansiyelinin ortaya konulmasının MBR teknolojisinin geleceği açısından önemli olduğu düşünülmektedir.

\section{Materyal ve Metot}

\subsection{Kullanılan Kimyasal Maddeler ve Cihazlar}

BisBAL sentezinde kullanılan propilen glikol $\left(\mathrm{C}_{3} \mathrm{H}_{8} \mathrm{O}_{2}, \geq \% 99,5\right.$, fcc $)$, bizmut nitrat pentahidrat $\left(\mathrm{Bi}\left(\mathrm{NO}_{3}\right) \cdot 5 \mathrm{H}_{2} \mathrm{O}\right.$ acs reagent $\left.\geq \% 98,0\right)$ ve 2,3 dimerkapto-1-propanol Sigma-Aldrich'ten temin edilmiştir. Tüm pH ayarlamaları $1 \mathrm{~N}$ $\mathrm{NaOH}$ ile (ekstra saf, Sigma-Aldrich, Almanya) ile gerçekleştirilmiştir. Bakteriler, saf kültür olarak Mikroorganizma Kültür Kolleksiyonları Araştırma ve uygulama Merkezi (KÜKENS)'nden temin edilmiştir. LB sıvı besiyeri Sigma-Aldrich'ten temin edilmiș tripton, maya, ve $\mathrm{NaCl}$ kullanılarak hazırlanmıștır. Çalıșmada kullanılan tüm cam ve plastik malzemeler $121^{\circ} \mathrm{C}$ sicaklık ve $1,06 \mathrm{bar}$ basınç koşullarında otoklavlanmıștır (NÜVE OT032, Türkiye). Optik yoğunluk (OD) değerleri
UV spektrofotometre (Pharmacia LKBNovaspek, ABD, quartz hücre ve $1 \mathrm{~cm}$ optik mesafe) kullanılarak ölçülmüştür.

\subsection{BisBAL Sentezi}

BisBAL sentezindeki koşulların optimizasyonu için üç parametre seçilmiștir: sıcaklık, $\mathrm{pH}$ ve Bis:BAL molarite oranları. Sicaklığın optimizasyonunda $25^{\circ} \mathrm{C}$ ve $45^{\circ} \mathrm{C}$ olmak üzere iki farklı ortam sıcaklığı denenmiștir. Asidik, nötral ve bazik koşulların simule edilebilmesi amacıyla 4,7 ve $10 \mathrm{pH}$ değerlerinde çalıșılmıștır. Son olarak, bizmut ve tiyol molar oranları (Bis:BAL) 3:1, 2:1 ve 1:1 olarak belirlenmiștir. Propilen glikol $\left(\mathrm{C}_{3} \mathrm{H}_{8} \mathrm{O}_{2}, \geq \% 99,5\right.$, fcc, Sigma-Aldrich, Almanya) içerisinde çözünmüş bizmut nitrat pentahidratın $\left(\mathrm{Bi}\left(\mathrm{NO}_{3}\right) \cdot 5 \mathrm{H}_{2} \mathrm{O}\right.$ acs reagent $\geq \% 98,0$, Sigma-Aldrich, Almanya) 2,3dimerkapto-1-propanol üzerine (Sigma-Aldrich, Almanya) ilave edilmiştir [23]. $\mathrm{pH}$ ayarlamaları $1 \mathrm{~N} \mathrm{NaOH}$ ile (ekstra saf, Sigma-Aldrich, Almanya) ile gerçekleștirilmiștir. Sıcaklık ayarı ise, sıcaklık ölçümü ile sıcaklığı ayarlayabilen ısıtıcılı karıștırıcılar ile gerçekleştirilmiştir. 18 farklı kombinasyon ile üretilen BisBAL kimyasallarının listesi daha önce gerçekleştirilmiş çalıșmada görülebilmektedir [24].

\subsection{Bakteri Kültürlerinin Hazırlanması}

\section{Bakteri Suşları}

Belirtildiği üzere, gram-negatif bakterileri temsil etmesi açısından E. coli tercih edilirken gram-pozitif bakteri olarak $S$. pyogenes ile çalıșılmıștır. Liyofilize halde alınan türlerin bilgileri Tablo 1'de verilmektedir.

Tablo 1. Suş bilgileri.

\begin{tabular}{ll} 
Suş Adı & Liyofilizasyon Tarihi \\
\hline E. coli & 12.08 .1998 \\
S. pyogenes & 13.02 .1994
\end{tabular}

Liyofilize bakteri ampüllerinin üst noktasının 2,5-3 cm așağısına bir kesik atılmıș ve alkole daldırılmış pamuk ile kesiği üzernde kalan kısım tutularak ampülün kırılması sağlanmıștır. Üst kısmı kırılmıș ampül dezenfektan dolu bir behere oturtulmuştur. Ardından, bu ampülün içerisine steril bir pastör pipet yardımı ile 0,2 $\mathrm{cm}^{3}$ Luria Bertani (LB) sivı besiyeri ilave edilmiștir. 


\section{Besiyeri Hazırlanışı}

LB sıvı besiyeri, 10 g/LTripton, 5 g/L maya, 5 $\mathrm{g} / \mathrm{L} \mathrm{NaCl}$ kullanılarak hazırlanmıștır. LB agar için ise bu kimyasallara ilave olarak $15 \mathrm{~g} / \mathrm{L}$ baktoagar kullanılmıştır. Solüsyonlar manyetik karıştırıcıda karıştırılmış ve $121^{\circ} \mathrm{C}$ sıcaklık ve 1,06 bar basınç koşullarında otoklavlanmıștır. Otoklavın ardından her bir agar plakaya $20 \mathrm{ml}$ LB agar solüsyonu dökülüp $60^{\circ} C^{\prime}$ ye gelene kadar bunsen alevinin yanında bekletilniștir. Yoğunlaşan buharın su damlaları şeklinde agarların üzerine dökülmesini engellemek amacıyla yarı açık bırakılan kapaklar kapatıldıktan sonra plakalar parafilmlenmiștir. Sıvı besi yerleri ise steril falkon tüplerine $5 \mathrm{ml}$ hacim ile doldurulmasının ardından tekrar otoklavlanarak hazırlanmıştır.

\section{İnokulasyon}

İnhibisyon testlerinde kullanılacak olan tekil koloniyi elde edebilmek adına LB agarlara inokulasyon (ekim) yapılmıștır. Bakteri süspansiyonundan steril öze ile alınan bir damla agara damlatılmıș ve çizgiler çizilerek plakanın dört çeyreğine de yayılmıştır. Her çeyrek için yapılacak ekim öncesi özenin ucu steril edilmiștir. 24 saatlik inkübasyonun sonucunda dördüncü çeyrekte tekil koloniler elde edilebilmiștir. Elde edilen tekil koloniler öze ile alınrak falkon tüplerdeki sıvı besiyerine aktarılmış ve $37^{\circ} \mathrm{C}^{\prime}$ de 24 saat inkübe edilmiştir. Tüm ekim işlemler iki tür için de aynı prosedürler ile gerçekleşririlmiş ve üçlü tekrar ile deneyler yapılmıștır. İșlemler karanlık, serin ve steril ortamlarda gerçekleştirilmiştir.

\section{Bakteri Sayımı}

İnhibisyon testlerinde kullanılacak olan bakteri süspansiyonlarındaki bakteri sayısının belirlenmesi için seyreltme motodu kullanılmıștır. Süspansiyonlar izotonik su kullanılarak $(1: 10,1: 100,1: 1000$ ve1:10000) seyreltilmiş ve membran filtrasyona tabi tutulmuștur. Membranlar, üzerlerindeki kalan bakteriler ile agar plakalara yatırılmış ve $37^{\circ} \mathrm{C}$ 'de 24 saat inkübe edilmiștir. İnkübasyon sonunda koloniler sayılmıştır ve deney bașlangıcındaki toplam bakteri sayısı her iki tür için de $2.10^{8} \mathrm{CFU} / \mathrm{ml}$ olarak belirlenmiştir.

\section{Aktif Çamur}

Tüm inhibisyon testleri saf kültürlerin yanı sıra aktif çamur yani karıșık kültür ile de gerçekleştirilmiştir. Aktif çamur, Paşaköy İleri
Biyolojik Atıksu Arıtma Tesisinin havalandırma tankından alınmıştır (İstanbul, Türkiye).

\section{4. İnhibisyon Testleri}

Falkon tüpler içerisinde saklanan steril sıvı besiyerlerinin $(5 \mathrm{ml})$ üzerine $0,2 \mathrm{ml}$ bakteri solüsyonu eklenmiștir. Ardından 24 saatlik inkübasyon gerçekleştrilmiştir. İnkübe bakteri solüsyonları yaklaşık olarak 8000 bakteri/L içerik elde edilecek şekilde izotonik su ile seyreltilmiştir. $\mathrm{Bu}$ şekilde hedef bir başlangıç bakteri içeriğinin seçilmesindeki sebep UV spektrofotometre okumalarında okuma limitlerinin üzerinde bir OD elde edilmesinin önüne geçilmesidir. Bakteri ilavesinin ardından çeşitli son molar konsantrasyonlar $(5,12,15$, 20, 30 ve $40 \mu \mathrm{M}$ ) doğrultusunda BisBAL eklemesi yapılmıştır. Hedef molar konsantrasyona ulaşmak için eklenecek BisBAL hem doğrudan ilave edilmiştir hem de seyreltilerek (aynı son molar konsantrasyona ulașacak șekilde) ilave edilerek seyreltmenin etkisi gözlenmek istenmiștir. BisBAL ilavelerinin ardından numuneler 24 saat inkübe edilmiş ve OD ölçümleri yapılmıştır.

\section{Doğrudan BisBAL İlavesi}

Sentezlenen 18 farklı BisBAL kimyasalı, doğrudan E. coli, S. pyogenes veyaaktif çamur içeren sıvı besiyerlerine ilave edilmiştir. Değișik BisBAL kimyasalları (S1, S2, ..., S18) hedef son molar konsantrasyonunun aynı olabilmesi için farklı miktarlarda ilave edilmiştir çünkü ekleme hacimleri Bis:BAL molar oranları $(1: 1,2: 1$ and 3:1) ile lineer bir ilişki içerisinde değildir. Ekleme hacimlerinin hesaplanması Denklem 1 'de verilmektedir. Sentezlenen BisBAL şelatlarının molar konsantrasyonları ise 3:1, 2:1 ve $1: 1$ oranları için sırası ile $67 \mathrm{mM}, 75 \mathrm{mM}$ ve 100 mM'dır. Eklenen hacim 0,4-2,7 $\mu$ l arasında değişmiştir.

$$
\mathrm{M}_{1} * \mathrm{~V}_{1}+\mathrm{M}_{2} * \mathrm{~V}_{2}=\mathrm{M}_{3} * \mathrm{~V}_{3}
$$

Burada;

$\mathrm{V}_{1}$ :İlave edilen BisBAL hacmi

$\mathrm{M}_{1}$ : İlave edilen BisBAL'ın molaritesi

M2: $\quad 0 \quad \mathrm{mM} \quad$ (LB sivi besiyeri+bakteri süspansiyonundaki BisBAL molaritesi sıfırdır.)

$\mathrm{M}_{3}: 5,12,15,20,30$ veya $40 \mu \mathrm{M}$

$\mathrm{V}_{3}:\left(5+\mathrm{V}_{1}\right) \mathrm{ml}$ 


\section{Seyreltilmiş BisBAL İlavesi}

Son BisBAL molar konsantrasyonu $\left(M_{3}\right)$ aynı olacak şekilde 100 kat seyreltilmiş (distile su ile) BisBAL ilavesi gerçekleștirilmiștir. Hacim hesaplamaları tekrar Denklem 1 kullanılarak yapılmıştır.

\section{Optik Yoğunluk Ölçümleri}

Doğrudan ve seyreltilmiș BisBAL ilavelerinin ardından inkübasyona tabi tutulan numunelerin ardından OD değerleri UV spektrofotometre ile ölçülmüştür. Ölçümler $420 \mathrm{~nm}$ dalga boyunda gerçekleştirilmiştir. Inhibisyon etkisi (IE) aşağıdaki şekilde hesaplanmıştır.

$$
\dot{I E}=\left(O D_{0 \mu M}-O D_{40 \mu M}\right) / O D_{0 \mu M} * 100
$$

Burada;

$\mathrm{OD}_{0 \mu \mathrm{M}}$ : $0 \mu \mathrm{MBisBAL}$ ilavesi olan numunenin OD değeri

OD $40 \mu \mathrm{m}: 40 \mu \mathrm{MBisBAL}$ ilave edilmiş numunenin OD değeri

\section{EPS ve SMP Analizleri}

En yüksek inhibisyonun gözlendiği beş BisBAL şelatı için (S1, S3, S6, S11 ve S14) doğrudan ve seyreltilmiş BisBAL ilavesi durumlarındaki minimum inhibisyon konsantrasyonlarının (MIK) gözlendiği numunelerde (sırası ile $15 \mu \mathrm{M}$ ve $30 \mu \mathrm{M}$ JEPS ve SMP analizleri de gerçekleştirilmiştir. EPS ve SMP ekstaksiyonları fiziksel ayrım metoduyla yapılmıștır. Ilk olarak, $5 \mathrm{ml}$ numune $4000 \mathrm{rpm}$ ve $4^{\circ} \mathrm{C}$ sicaklıkta 10 dakika süreyle santrifüj edilmiştir. Ardından, üst faz $13200 \mathrm{rpm}$ ve $4^{\circ} \mathrm{C}$ sicaklıkta 20 dakika süreyle santrifüj edilmiştir. İkinci santrifüjün üst fazı SMP'yi temsil etmiștir. İlk santrifüjün peleti $5 \mathrm{ml}$ distile su ile tekrardan süspanse hale getirilmiștir. Bu süspansiyona $6 \mu \mathrm{L}$ formaldehit (\%37) ilave edilmiștir ve $4^{\circ} \mathrm{C}$ sicaklıkta 1 saat bekletilmiştir. Bir saatin sonunda $0,5 \mathrm{ml} \mathrm{NaOH}$ $(1 \mathrm{~N})$ eklenmiştir ve $4^{\circ} \mathrm{C}$ sicaklıkta 3 saat saklanmıștır. Ardından $13200 \mathrm{rpm}$ ve $4^{\circ} \mathrm{C}$ sıcaklıkta 20 dakika süreyle santrifüj uygulanmıștır ve bu üst faz EPS'yi temsilen kullanılmıştır. Elde edilen EPS ve SMP bileșenlerinin protein ve karbonhidrat içerikleri de ortaya koymak amacı ile sırası ile Lowry ve Fenol sülfürik asit [25] metotları kullanılmıştır.

\section{Karışık Kültür ile İnhibisyon Testi}

Aktif çamurdaki bakteri sayımı gerçekleştirilmiş ve inhibisyon testinin başlangıcındaki bakteri sayısının saf kültür çaışmasındaki bakteri sayısına denk olmasına dikkat edilmiștir. Aktif çamur üzerindeki inhibisyon etkisi doğrudan BisBAL (S3) ilavesi ile değişik son molar konsantrasyonlar $(5,12,15,20,30$ ve $40 \mu \mathrm{M})$ ile çalıșılmıştır. 24 saatlik inkübasyonun sonucunda OD değerleri ölçülmüştür.

Tüm inhibisyon çalıșmalarının sonunda BisBAL kimyasalının stabilitesi de kontrol edilmiștir. $\mathrm{Bu}$ amaçla 12 hafta boyunda haftalık periyotlar ile inhibisyon deneylerine devam edilmiştir.

\section{Bulgular}

\subsection{BisBAL Sentezi Optimizasyonu}

Bu çalışmada, $\mathrm{pH}$, sıcaklık ve Bis:BAL molar konsantrasyon oranlarının optimize edilmesi amacıyla 18 farklı BisBAL şelatları sentezlenerek, sentezlenen bu kimyasalların farklı oldukları çıplak gözle gözlenebilen renk değişimlerinden anlaşılmıştır. Aynı sıcaklık ve bizmut içeriği ile sentezlenen BisBAL'lar farklı $\mathrm{pH}$ değerlerinde sentezlendiğinde değişik renklere sahip olmuşlardır. pH'ın düşmesi ile birlikte renk öncelikle yeşilden sarıya ardından somon rengine dönmüștür. $\mathrm{Bu}$ renk değişikliğinin sebebi BAL tiyolünün bünyesindeki sülfürün değişik pH koşullarında farklı kimyasal bağlar oluşturması şeklinde yorumlanmıștır. Buna ek olarak, sıcaklığın artması ile daha heterojen ve koyu renkte kimyasalların elde edildiği de söylenebilir. Sentezlenen kimyasalların görüntüleri Ek dosyasında Şekil Ek.1 olarak sunulmuştur.

\section{2. İnhibisyon Çalışmaları}

\section{Doğrudan BisBAL İlavesinin $E$. coli Üzerindeki Etkisi}

İnhibitör olarak kullanılan BisBAL kimyasalı çeșitli hacimlerde bakteri süspansiyonlarına ilave edilmiş ve MiK değerinin belirlenmesine çalıșılmıștır. E. coli numunelerinde 24 saatin sonunda okunan OD değerleri Şekil 1'de verilmektedir. İnhibisyon profilleri, sonuçların daha net sergilenebilmesi açısından 6 grup halinde sunulmuştur: Grup I (S1, S2 ve S3), Grup II (S4, S5 ve S6), Grup III (S7, S8 ve S9), Grup IV (S10, S11 ve S12), Grup V (S13, S14 ve S15), ve Grup VI (S16, S17 ve S18). Optimum sentez koşullarının belirlenmesi adına inhibisyon profilleri incelenmiş ve $E$. coli türü için 15 $\mu M^{\prime}$ dan yüksek BisBAL konsantrasyonlarında önemli MİK $15 \mu \mathrm{M}$ olarak belirlenmiştir. BisBAL konsantrasyonunun arttırılması ile birlikte inhibisyon etkisi de hızla artmıştır. $\mathrm{Bu}$ tür üzerinde en etkili olan kombinasyonlar S3, S6 
ve S18 olarak belirlenmiştir. Inhibisyon etkisi \%42-93 aralığında değișiklik göstermekteyken, en etkili kombinasyonların inhibisyon etkisi ise \%79-93 aralığında değișmiștir (Şekil 2).

Doğrudan BisBAL İlavesinin $S$, pyogenes Üzerindeki Etkisi

$S$. pyogenes üzerindeki etkinin inhibisyon profilleri ile ortaya konulmasında $E$. coli çalışmasında olduğu için 6 grup halinde grafiklendirme tercih edilmiştir (Şekil 3).IE
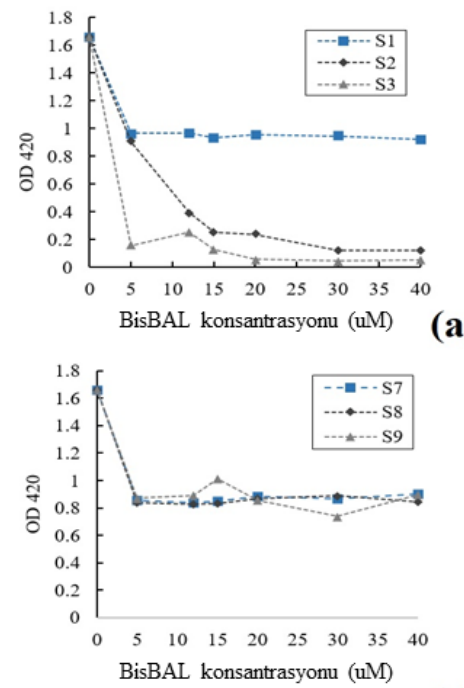

(a)

değerleri ise Şekil 4'te sunulmuştur. Açık bir şekilde görülebileceği üzere, $15 \mu \mathrm{M}^{\prime}$ dan yüksek konsantrasyonlarda bakterinin çoğalması imkansız hale gelmiștir. En başarılı kombinasyonlar S3, S11 ve S1 olarak belirlenmiștir. İE değerleri ise \%65-90 aralında seyretmiştir. Sonuçların ışığında, $S$. pyogenes türünün $E$. coli türünden daha fazla etkilendiği söylenebilir. Bu sonuç, gram-pozitif bakterilerin gram-negatif bakterilerden daha hassas olduğu bilindiğinden olağan bir sonuçtur.
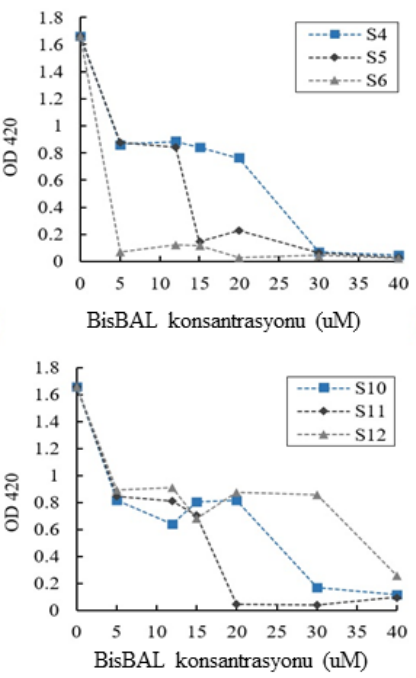

(c)
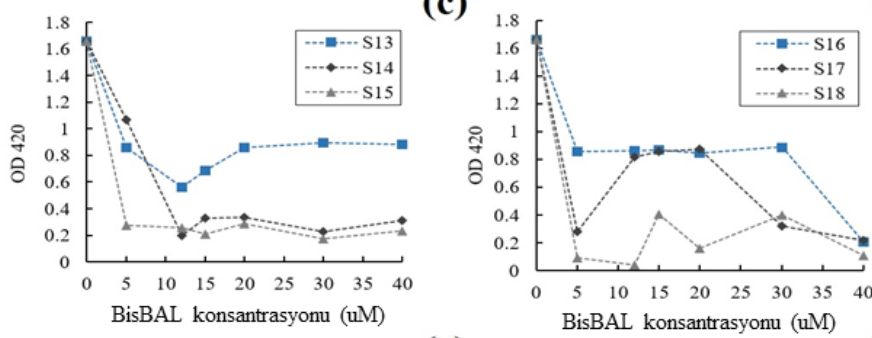

(e)

Şekil 1. BisBAL’ın E. coli üzerindeki etkisinin profilleri 
DEU FMD 21(62), 499-508, 2019

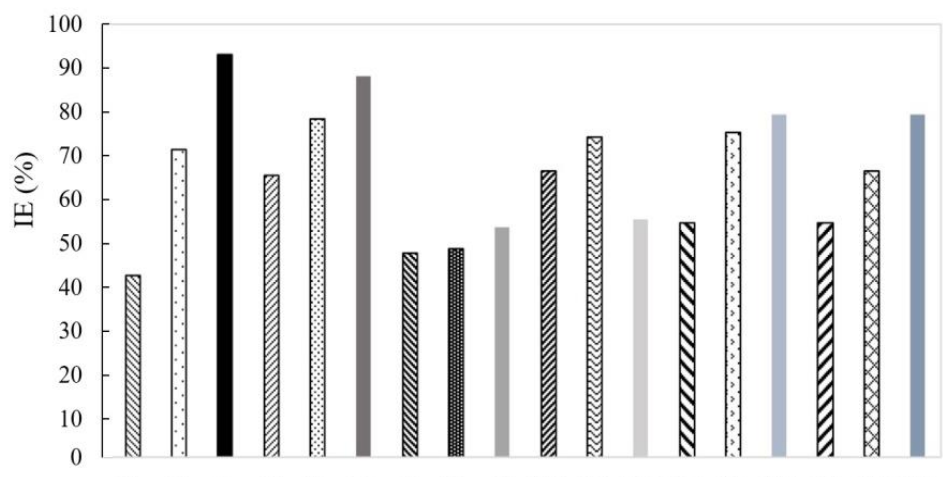

$\begin{array}{lllllllllllllllllllll}\text { S1 } & \text { S2 } & \text { S3 } & \text { S4 } & \text { S5 } & \text { S6 } & \text { S7 } & \text { S8 } & \text { S9 } & \text { S10 } & \text { S11 } & \text { S12 } & \text { S13 } & \text { S14 } & \text { S15 } & \text { S16 } & \text { S17 } & \text { S18 }\end{array}$

Şekil 2. Escherichia coli üzerindeki etkisinin İE değerleri
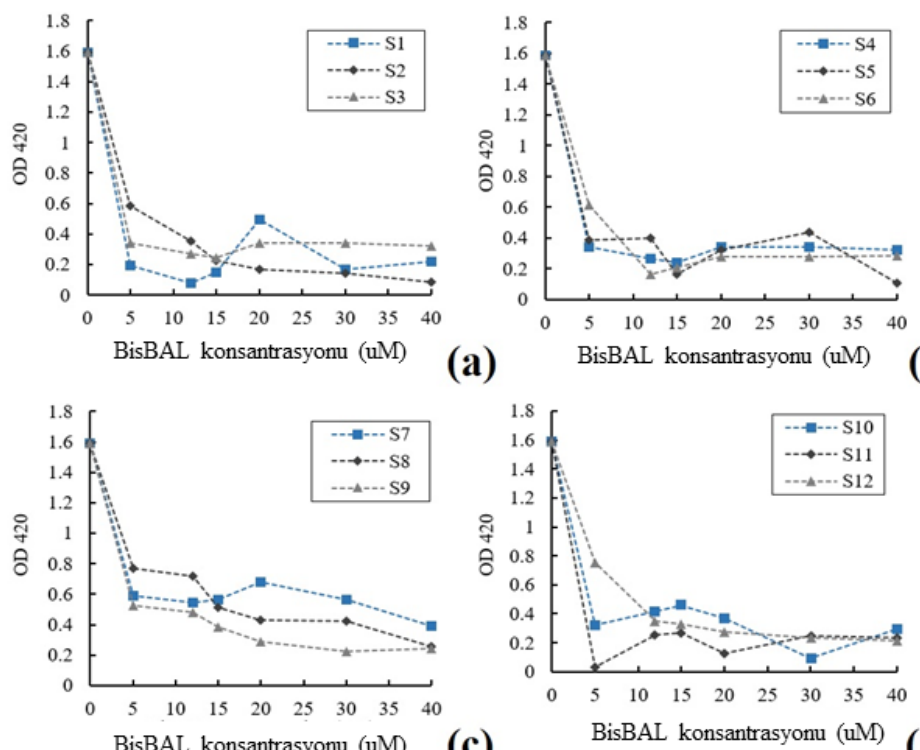

(a)

(b)

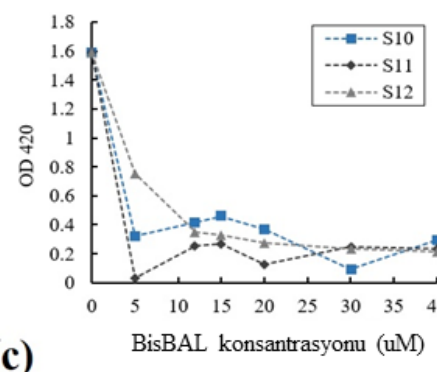

(d)
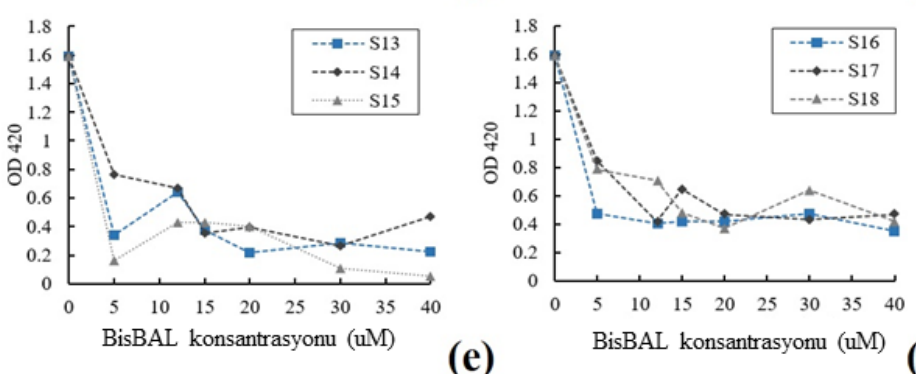

Şekil 3. BisBAL'ın S. pyogenes üzerindeki etkisinin profilleri 


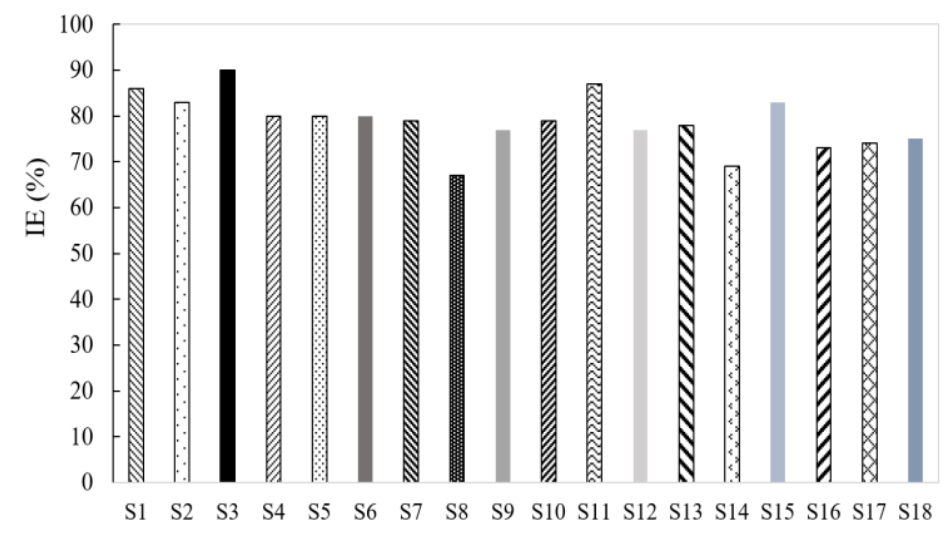

Şekil 4. S. pyogenes üzerindeki etkisinin İE değerleri

\section{Seyreltilmiş BisBAL İlavesi ve İnkübasyon Süresinin İE Üzerindeki Etkisi}

Gerçek ölçekli membran ve/veya başka bir mühendislik ürünü üretiminde BisBAL ilavesinin seyreltilmiş olarak yapılabileceği ihtimali de göz önüne alındığından böyle bir uygulamanın inhibisyon üzerine etkisi de çalışılmıştır. Son molar konsantrasyon aynı olacak şekilde seyreltik BisBAL'dan daha fazla ilave edilmiş ve 24 saatin sonun OD değerleri incelenmiştir. Inhibisyon profilleri incelendiğinde (data sunulmamıștır) MIK değerinin E. coli türü için $30 \mu \mathrm{M}$ olduğu görülmüştür. İE yüzdeleri ise ilave edilen bizmut metalinin son molaritesi aynı olmasına rağmen düşmüștür. İE yüzdelerinde an az düşüş S3, S6 ve S18 kimyasallarında gözlenmiștir ki bu kombinasyonlar doğrudan ilavelerde de en yüksek inhibisyon etkisini gösteren kombinasyonlardır. İE'deki ortalama düșüș doğrudan ilave çalışmaları ile karşılatırıldığında \%50 civarında olmuştur. İnhibisyon etkisi bazı durumlarda sıfır seviyelerine inmiș ve hatta az sayıda numunede türün inhibitör varlığında büyümeye devam edebildiği görülmüştür. $S$. pyogenes ile gerçekleștirilen çalışmalarda ise inhibisyon etkisindeki ortalama düşüş \%5 civarında olmuştur. Bunun sebebi olarak, bu türün zaten hali hazrıda daha hassas olması ve su ile seyreltilmiş inhibitöre maruz kalmanın bile etkili olabilmesi gösterilebilir.

48 saat devam eden inkübasyonun sonuçları incelendiğinde ise, doğrudan BisBAL ilavesinde dahi ilk 24 saat sonrasında inhibisyon etkisinin azalmaya başladığı fakat ancak inhibitör konsantrasyonu $15 \mu$ M'dan yüksek olduğu durumlarda inhibisyon etkisinin sürdürülebilir olduğu görülmüştür. Her iki tür için de İE değerleri \%80-92 aralığında değişmiştir.

\section{BisBAL'in EPS ve SMP Üzerindeki Etkisi}

En etkili üç BisBAL kmyasalı ile (S1, S3 ve S6) gerçekleștirilen deneylerde 24 saatin sonunda EPS ve SMP'nin protein ve karbonhidrat içerikleri ölçülmüştür. EPS'nin protein içeriği açısından bakıldığında, $E$. coli türünün salgılanması \%43-59 oranında azalmakta iken S. pyogenes türünde bu salgılama azalması $\% 23-$ 68 oranında seyretmistir. EPS'nin karbonhidrat içeriğinin salgılanması ise her iki türde de \%100 azaltılmıştır.

\section{BisBAL'ın Karışık Kültür Üzerindeki Etkisi}

Tek bir BisBAL kimyasalı (S3) ile aktif çamur üzerinde gerçekleştirilen inhibisyon çalışmaları sonucunda elde edilen inhibisyon profili grafiği Şekil 5'te verilmiştir. Şekilde görüldügü üzere, MİK değeri $15 \mu \mathrm{M}$ olarak elde edilmiștir. $\mathrm{Bu}$ değer, E. coli ve $S$. pyogenes ile yürütülen saf kültürde inhibisyon çalışmalarında elde edilen sonuç ile aynıdır. Karışık kültür üzerinde inhibisyon etkisi \%93 olmuştur.

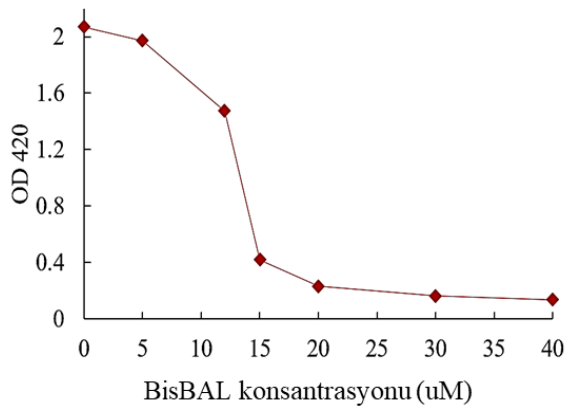

Şekil 5.Aktif çamur için inhibisyon profili 


\section{BisBAL'In Stabilitesi}

Doğada bulunmayan laboratuvar ortamında sentezlenen antibakteriyel kimyasallar zaman içerisinde inhibisyon etkilerini kaybetmektedirler. Böyle olası bir durumu kontrol edebilmek amacı ile en etkili BisBAL kimyasalı (S3)'nın E. coli türü üzerindekietkisi uzun süreli olarak (106 gün boyunca) araștırılmıștır. İnhibisyon profili Șekil $6^{\prime}$ da görülebilir. İnhibisyon etkisi ilk günden başlayarak azalmaktadır fakat azalma hızının düşük olduğu söylenebilir.

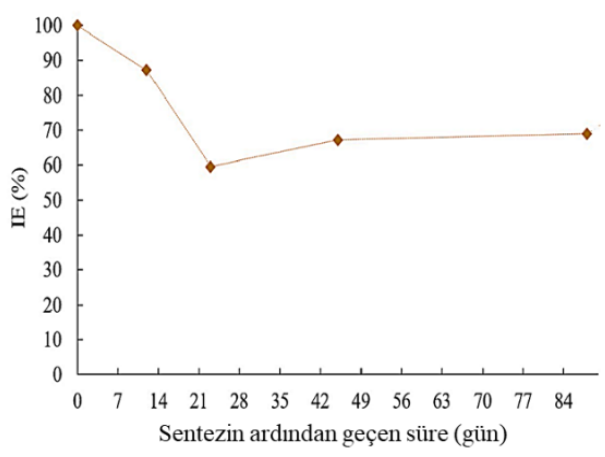

Şekil 6.Aktif çamur için inhibisyon profili

\section{Teşekkür}

Bu çalıșma TÜBİTAK tarafından desteklenmiștir (Proje No:111Y275).

\section{Kaynakça}

[1] Padaki, M., Murali, R. S., Abdullah, M. S., Misdan, N., Moslehyani, A., Kassim, M. A. \& Ismail, A. F. 2015. Membrane technology enhancement in oil-water separation. A review. Desalination, 357, s. 197-207.

[2] Fazal, S., Zhang, B., Zhong, Z., Gao, L., Chen, X. 2015. Industrial wastewater treatment by using MBR (membrane bioreactor) review study. Journal of Environmental Protection, 6(06), s. 584.

[3] Lee, S. H., Hong, T. I., Kim, B., Hong, S., Park, H. D. 2014. Comparison of bacterial communities of biofilms formed on different membrane surfaces. World Journal of Microbiology and Biotechnology, $30(2)$, s. 777-782.

[4] Luo, J., Lv, P., Zhang, J., Fane, A. G., McDougald, D., Rice, S. A. 2017. Succession of biofilm communities responsible for biofouling of membrane bioreactors (MBRs). PloS one, 12(7), e0179855.

[5] Gurunathan, S., Han, J. W., Kwon, D. N., Kim, J. H. 2014. Enhanced antibacterial and anti-biofilm activities of silver nanoparticles against Gramnegative and Gram-positive bacteria. Nanoscale research letters, 9(1), s. 373.

\section{Tartışma ve Sonuç}

Bu çalışmada, kullanılan Bis:BAL oranı optimize edilmiştir. Antibakteriyel kimyasalın hem saf kültürler olan E. coli ve $S$. pyogenes hem de karışık bir kültür olan aktif çamur üzerindeki inhibisyon etkisi ortaya konulmuştur. Grampozitif ve gram-negatif bakteriler üzerindeki etkilerinde farklılıklar gözlenmiştir. Grampozitif bakteriler daha kolay etkilenirken, karışık kültür aktif çamur da saf kültür $E$. coli'den daha fazla etkilenmiștir. Sentez sırasındaki çevresel koşulların önemi de ortaya konulmuştur. En etkili antibakteriyel BisBAL, oda sıcaklığında, asidik pH'ta (pH:4) ve 1:1 Bis:BAL oranında sentezlenen kimyasal olmuştur. Buna dayanarak eș molar konsantrasyonlarındaki bizmut metali ve tiyol grubu ilavesi ile tiyolün doğal $\mathrm{pH}$ 'sına yakın asidik bir $\mathrm{pH}$ değerinde (pH:4) çalışmanın başarısını artırdığı söylenebilir. Bakteri büyümesini kolayca engelleyebilen BisBAL aynı zmanda canlılığını devam ettirebilen kalan bakterilerin de protein sentezini yavaşlatmış, karbonhidrat sentezini de tamamen durdurmuştur. Sonuç olarak, anti-biyotıkanma çalışmalarında kullanılabilmesi mümkün yenilikçi ve üretimi kolay bir kimyasal sentezi ortaya konulabilmiştir.

[6] Lee, W., Kim, K. J., Lee, D. G. 2014. A novel mechanism for the antibacterial effect of silver nanoparticles on Escherichia coli. Biometals, 27(6), s. 1191-1201.

[7] Priyadarshini, E., Pradhan, N., Sukla, L. B., Panda, P. K. 2014. Controlled synthesis of gold nanoparticles using Aspergillus terreus IF0 and its antibacterial potential against Gram negative pathogenic bacteria. Journal of Nanotechnology, 2014.

[8] Suganya, K. U., Govindaraju, K., Kumar, V. G., Dhas, T. S., Karthick, V., Singaravelu, G., Elanchezhiyan, M. 2015. Blue green alga mediated synthesis of gold nanoparticles and its antibacterial efficacy against Gram positive organisms. Materials Science and Engineering: C, 47, s. 351-356.

[9] Sirelkhatim, A., Mahmud, S., Seeni, A., Kaus, N. H. M., Ann, L. C., Bakhori, S. K. M., Mohamad, D. 2015. Review on zinc oxide nanoparticles: antibacterial activity and toxicity mechanism. Nano-Micro Letters, 7(3), s. 219-242.

[10] Meghana, S., Kabra, P., Chakraborty, S., Padmavathy, N. 2015. Understanding the pathway of antibacterial activity of copper oxide nanoparticles. RSC advances, 5(16), s. 12293-12299.

[11] Besinis, A., Hadi, S. D., Le, H. R., Tredwin, C., Handy, R. D. 2017. Antibacterial activity and biofilm inhibition by surface modified titanium alloy medical implants following application of silver, 


\section{DEU FMD 21(62), 499-508, 2019}

titanium dioxide and hydroxyapatite nanocoatings. Nanotoxicology, 11(3), s. 327-338.

[12] Verma, P. 2015. A Review on Synthesis and Their Antibacterial Activity of Silver and Selenium Nanoparticles against Biofilm Forming Staphylococcus Aureus. World J. Pharm Pharmaceut. Sci, 4, s. 652-677.

[13] Stolzoff, M., Wang, S. Q., Webster, T. J. 2016. Efficacy and mechanism of selenium nanoparticles as antibacterial agents. In Front. Bioeng. Biotechnol. Conference Abstract: 10th World Biomaterials Congress. s. 3040 .

[14] Barton, L. L., Lyle, D. A., Ritz, N. L., Granat, A. S., Khurshid, A. N., Kherbik, N., Lin, H. C. 2016. Bismuth (III) deferiprone effectively inhibits growth of Desulfovibrio desulfuricans ATCC 27774. BioMetals, 29(2), s. 311-319.

[15] Flores-Castañeda, M., Vega-Jiménez, A. L., AlmaguerFlores, A., Camps, E., Pérez, M., Silva-Bermudez, P., Rodil, S. E. 2015. Antibacterial effect of bismuth subsalicylate nanoparticles synthesized by laser ablation. Journal of Nanoparticle Research, 17(11), s. 431 .

[16] Hernandez-Delgadillo, R., Del Angel-Mosqueda, C., Solís-Soto, J. M., Munguia-Moreno, S., PinedaAguilar, N., Sánchez-Nájera, R. I., Cabral-Romero, C. 2017. Antimicrobial and antibiofilm activities of MTA supplemented with bismuth lipophilic nanoparticles. Dental Materials Journal, 36(4), s. 503-510.

[17] Mahdiun, F., Mansouri, S., Khazaeli, P., Mirzaei, R. 2017. The effect of tobramycin incorporated with bismuth-ethanedithiol loaded on niosomes on the quorum sensing and biofilm formation of Pseudomonas aeruginosa. Microbial pathogenesis, 107, s. 129-135.

[18] Li, M., Bradley, J. C., Badireddy, A. R., Lu, H. 2017 Ultrafiltration membranes functionalized with lipophilic bismuth dimercaptopropanol nanoparticles: Anti-fouling behavior and mechanisms. Chemical Engineering Journal, 313, s. 293-300.

[19] Badireddy, A. R., Hernandez-Delgadillo, R., SánchezNájera, R. I., Chellam, S., Cabral-Romero, C. 2014 Synthesis and characterization of lipophilic bismuth dimercaptopropanol nanoparticles and their effects on oral microorganisms growth and biofilm formation. Journal of Nanoparticle Research, 16(6), s. 2456.

[20] Franci, G., Falanga, A., Galdiero, S., Palomba, L., Rai, M., Morelli, G., Galdiero, M. 2015. Silver nanoparticles as potential antibacterial agents. Molecules, 20(5), s. 8856-8874.

[21] Abbaszadegan, A., Ghahramani, Y., Gholami, A., Hemmateenejad, B., Dorostkar, S., Nabavizadeh, M., Sharghi, H. 2015. The effect of charge at the surface of silver nanoparticles on antimicrobial activity against gram-positive and gram-negative bacteria: a preliminary study. Journal of Nanomaterials, 16(1), s. 53
[22] Varposhti, M., Ali, A. A., Mohammadi, P. 2014. Synergistic effects of Bismuth Thiols and various antibiotics against Pseudomonas aeruginosa biofilm. Jundishapur Journal of Microbiology, 7(3).

[23] Badireddy A. R., Chellam S., Yanina S., Gassman P., Rosso K. M. 2008. BisBAL inhibits the expression of extracellular polysaccharides and proteins by Brevundimonas diminuta Implications for membrane microfiltration. Biotechnology and Bioengineering, 99(3)

[24] Ovez S., Turken T., Kose-Mutlu B., Okatan S., Durmaz G., Guclu M. C., Koyuncu I. 2016. Manufacturing of antibiofouling polymeric membranes with bismuthBAL chelate (BisBAL). Desalination and Water Treatment, 57(28), s. 12941-12955. 